\title{
Cadmium isotope fractionation in soil-wheat systems
}

\author{
Supporting Information
}

Matthias Wiggenhauser ${ }^{\star,}{ }^{\dagger}$, Moritz Bigalke $^{\ddagger}$, Martin Imseng ${ }^{\ddagger}$, Michael Müller", Armin Keller", Katy Murphy ${ }^{\perp}$, Katharina Kreissig ${ }^{\perp}$, Mark Rehkämper ${ }^{\perp}$, Wolfgang Wilcke ${ }^{\S}$, Emmanuel Frossard $^{+}$

\footnotetext{
${ }^{*}$ Institute of Agricultural Sciences, ETH Zurich, Eschikon 33, CH-8315 Lindau, Switzerland ${ }^{\ddagger}$ Institute of Geography, University of Bern, Hallerstr. 12, CH-3012 Bern

\&Institute of Geography and Geoecology, Karlsruhe Institute of Technology (KIT), P.O. Box 6980, D-76049 Karlsruhe "Swiss Soil Monitoring Network (NABO), Agroscope, Reckenholzstrasse 191, CH-8046 Zürich ${ }^{\perp}$ Department of Earth Science and Engineering, Imperial College London, London SW7 2AZ, UK
} 


\section{Contents}

1. Materials and Methods (detailed information) .................................................................... 4

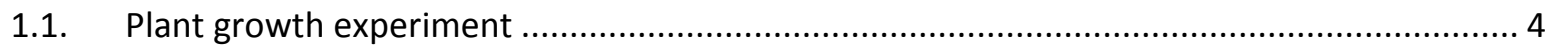

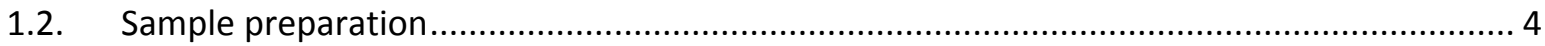

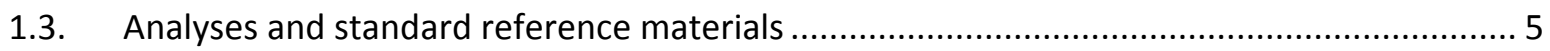

2. Cadmium isotope compositions and concentrations of standard reference materials (SRMs) ..... 7

3. Soil properties of Oensingen (Oen), Landquart (LQ) and Wiedlisbach (Wied)........................... 8

4. DM production, $\mathrm{Cd}$ concentration and $\mathrm{Cd}$ uptake of wheat .................................................. 9

5. Distribution of $\mathrm{Cd}$, macro and micronutrients in wheat.......................................................... 10

6. Apparent isotope fractionation between $\mathrm{A}$ horizon and $\mathrm{Ca}\left(\mathrm{NO}_{3}\right)_{2}$ extract ............................. 14

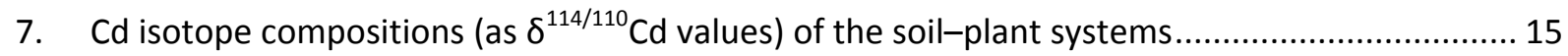

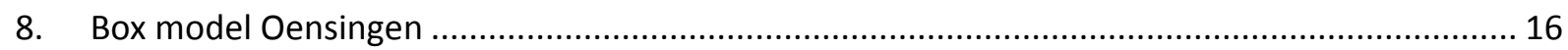

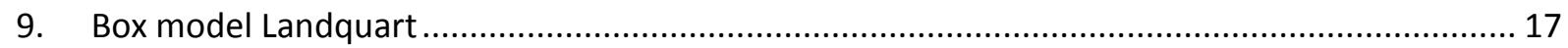

10. Comparison with published $\mathrm{Cd}$ isotope data for terrestrial and aquatic environments .......... 18

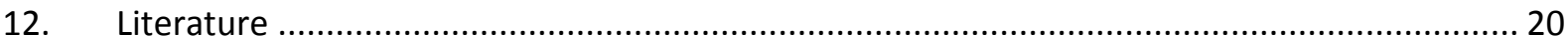




\section{Tables}

Table S1: Summary standard reference materials ..................................................................... 7

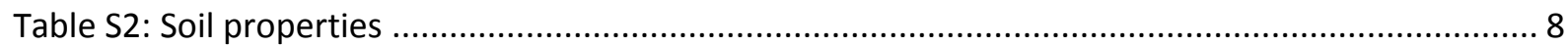

Table S3: Element concentrations measured in the different wheat parts. .................................... 11

Table S4:: Cadmium isotope compositions (as $\delta^{114 / 110} \mathrm{Cd}$ ) of the soil-wheat systems......................... 15

\section{Figures}

Figure S1: Dry matter production, $\mathrm{Cd}$ concentration and Cd uptake of wheat .................................. 9

Figure S2: Relative distribution of $\mathrm{Cd}$, macro and micronutrients in wheat ..................................... 10

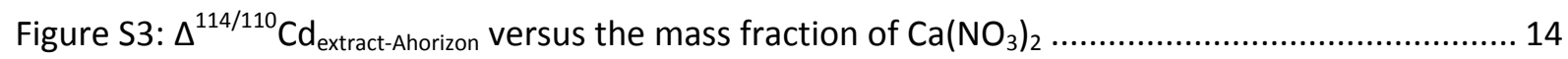

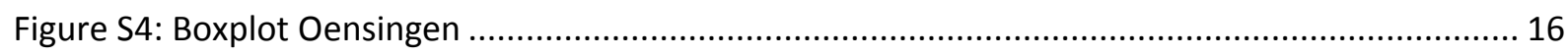

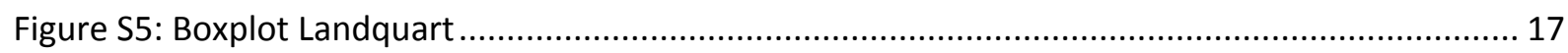

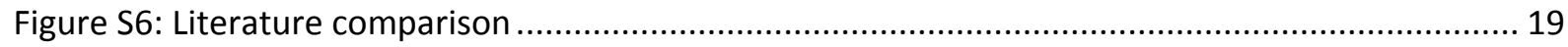




\section{Materials and Methods (detailed information)}

\subsection{Plant growth experiment}

To ensure regular plant growth, $100 \mathrm{mg} \mathrm{N}\left(80 \mathrm{mg} \mathrm{N}\right.$ applied as $\mathrm{Ca}\left(\mathrm{NO}_{3}\right)_{2}$ and $20 \mathrm{mg}$ as $\mathrm{NH}_{4} \mathrm{NO}_{3}$ ), 35 mg P $\left(\mathrm{KH}_{2} \mathrm{PO}_{4}\right), 50 \mathrm{mg} \mathrm{K}\left(\mathrm{K}_{2} \mathrm{SO}_{4}\right), 25 \mathrm{mg} \mathrm{Mg}\left(\mathrm{MgSO}_{4}\right), 5 \mathrm{mg}$ Fe (Fe-EDTA) and $2 \mathrm{mg} \mathrm{Zn}\left(\mathrm{ZnSO}_{4}\right)$ were added to each pot and mixed thoroughly.

The wheat plants were cultivated in a growth chamber with the following settings: photoperiod $16 \mathrm{~h}$, illuminance $25 \mathrm{klx}$, temperature $24^{\circ} \mathrm{C}$ at daytime and $16^{\circ} \mathrm{C}$ at night, humidity $60 \%$. The wheat was watered to maintain a range of 40 to $70 \%$ of the maximal water holding capacity (Table S2).

\subsection{Sample preparation}

The roots were rinsed with $6 \mathrm{mM} \mathrm{NaNO}_{3}$ and transferred for $15 \mathrm{~min}$ into a $6 \mathrm{mM} \mathrm{NaNO}_{3}$ cleaning bath followed by rinsing with the same solution. Cleaning bath $(5 \mathrm{~min})$ and rinsing were repeated up to three times until the roots and waste cleaning solution were visibly free of any soil particles. Sodium nitrate was chosen to disperse the clay minerals that adhered to the roots. ${ }^{1}$ The concentration of the cleaning solution was adapted to the equivalent of the conductivity ${ }^{2}$ in soil solutions obtained in currently running field studies at the same study sites (own, unpublished results).

To digest the plants in the high pressure single reaction chamber microwave system (turboWave, MWS microwave systems), $1 \mathrm{~g}$ portions of material were treated using $12 \mathrm{ml} 8 \mathrm{M} \mathrm{HNO}_{3}$. The $\mathrm{A}$ and $\mathrm{C}$ horizon of the soils were digested using a mixture of $8 \mathrm{ml} 16 \mathrm{M} \mathrm{HNO}_{3}$ and $2 \mathrm{ml} 24 \mathrm{M} \mathrm{HF}$ (Milestone, SK-10 high pressure rotor). Several digestion batches of one sample were combined to achieve a minimum quantity of $100 \mathrm{ng} \mathrm{Cd}$ for isotopic analysis. 


\subsection{Analyses and standard reference materials}

Application of the double spike methodology for the $\mathrm{Cd}$ isotope analyses ensured that results were unbiased by any isotope fractionation induced by the $\mathrm{Cd}$ separation chemistry and enabled precise correction for the large instrumental mass bias incurred in MC-ICP-MS. Additionally, use of the double spike facilitated precise determination of $\mathrm{Cd}$ concentrations by isotope dilution (ID). ${ }^{3}$ To this end, an appropriate volume of the ${ }^{111} \mathrm{Cd}-{ }^{113} \mathrm{Cd}$ double spike solution was equilibrated with the samples after digestion. ${ }^{4}$ Cadmium was then separated from the sample matrix using a three-stage separation chemistry that employs both anion exchange and extraction chromatography. ${ }^{4,5}$ This was followed by a liquid-liquid extraction step for sample cleanup. ${ }^{5}$

Cadmium concentrations determined by ID-MC-ICP-MS for plant and soil samples $(n=2-3)$ were employed to investigate the relationship between $\mathrm{Cd}$ pool sizes and $\mathrm{Cd}$ isotope fractionation (Table 1, Figure 3, Figure S3). The Cd concentrations of all plant samples were also measured by quadrupole ICP-MS without prior matrix separation. These results exceeded the $\mathrm{Cd}$ abundances determined by ID-MC-ICP-MS by $7.5 \pm 2.0 \%$ (1se). The quadrupole ICP-MS Cd data were used to compare the Cd concentrations and Cd quantities of plant samples ( $n=4$; Figure S1).

A number of standard reference materials (SRMs) were analyzed during the course of the study for quality control, with results summarized in Table S1. The performance of the MC-ICP-MS instrument was routinely monitored based on multiple analyses of SRM BAM I012 Cd. These measurements yielded $\delta^{114 / 110} \mathrm{Cd}=-1.30 \pm 0.09(2 \mathrm{sd}, \mathrm{n}=12)$, in good agreement with the consensus value of $-1.33 \pm$ $0.04 .^{6}$

The Cd isotope compositions and contents of three geological and biological SRMs with matrices and Cd concentrations similar to those of the experimental samples were also analyzed. These were andesite rock USGS SRM AGV-2, soil NIST SRM 2709a, and wheat flour NIST SRM 1567b (Table S1). The Cd concentrations of the SRMs were determined using the added double spike for ID calculations. $^{3}$ The $\mathrm{Cd}$ isotope data acquired for these SRMs showed good reproducibilities of 
between $0.02 \%$ and $0.11 \%$ o $(2 \mathrm{sd}, \mathrm{n}=2-6)$, as determined from multiple analyses of separately treated sample aliquots (Table S1). Isotopic reference data are unfortunately not available for these SRMs.

The Cd concentrations obtained for the SRMs are indicative of good Cd recoveries for soil NIST SRM 2709a (96 $\pm 3 \%, 2$ sd) and rock USGS SRM AGV-2. For the latter sample, recent independent analyses conducted at Imperial College yielded a Cd concentration of $67.7 \mathrm{ng} \mathrm{g}^{-1}$ (own, unpublished result), in excellent agreement with the present result of $66.6 \pm 0.03 \mathrm{ng} \mathrm{g}^{-1}(2 \mathrm{sd}, \mathrm{n}=2)$. Notably, other recent studies reported Cd contents of between about 60 and $3000 \mathrm{ng} \mathrm{g}^{-1}$ for this sample, indicating that $\mathrm{Cd}$ may be heterogeneously distributed in the powder. ${ }^{7}$ There is, however, a small but clearly resolvable discrepancy between the Cd concentration determined here for wheat flour NIST 1567b and the reference value. In detail, our analyses indicate a Cd recovery of only $88 \pm 8 \%(2 s d, n=6)$. The $C d$ recovery for this SRM did not improve when initially undigested silicates were treated with HF for full dissolution. The low recovery may hence reflect a slightly erroneous reference value for this sample. This conclusion is based on the observation that the certified Cd concentration of $254 \pm 0.9 \mathrm{ng} \mathrm{g}^{-1}$ was not determined on the actual NIST SRM 1567b material but adopted from the Cd concentration measured for the original NIST 1567a sample. ${ }^{8}$ 


\section{Cadmium isotope compositions and concentrations of standard reference materials (SRMs)}

Table S1: Summary standard reference materials

\begin{tabular}{|c|c|c|c|c|c|c|}
\hline SRM & Type & $\begin{array}{c}\delta^{114 / 110} \mathrm{Cd} \pm 2 s d^{\mathrm{a}} \\
(\%)\end{array}$ & $\begin{array}{c}\text { Reference } \\
(\%)\end{array}$ & $\begin{array}{c}\text { Cd conc. } \pm 2 s^{a} \\
\left(\mu g^{-1}\right)\end{array}$ & $\begin{array}{c}\text { Reference } \\
\left(\mu \mathrm{g} \mathrm{g}^{-1}\right)\end{array}$ & $\mathbf{n}$ \\
\hline NIST 2709a & Soil & $-0.22 \pm 0.02$ & - & $0.356 \pm 0.01$ & 0.371 & 2 \\
\hline NIST 1567b & Wheat flour & $0.93 \pm 0.08$ & - & $0.0216 \pm 0.0019$ & 0.0254 & 6 \\
\hline USGS AGV-2 & Andesite rock & $0.11 \pm 0.11$ & - & $0.0666 \pm 0.0003$ & $0.063-0.34^{c}$ & $2^{b}$ \\
\hline BAM-I012 & Isotopic RM & $1.30 \pm 0.09$ & $-1.33 \pm 0.04^{d}$ & - & - & 12 \\
\hline
\end{tabular}

a $2 \mathrm{sd}=2 \times$ standard deviation of $\mathrm{n}$ samples.

${ }^{\mathrm{b}} \mathrm{A}$ single sample was digested and spiked and then split into two samples for which column chemistry and isotopic analyses were done separately.

${ }^{c}$ Values summarized from GeoReM ${ }^{7}$

${ }^{d}$ Mean value from Abouchami et al. (2013) 


\section{Soil properties of Oensingen (Oen), Landquart (LQ) and Wiedlisbach (Wied).}

Table S2: Soil properties

\begin{tabular}{|c|c|c|c|c|c|c|c|c|c|c|c|c|c|}
\hline \multicolumn{4}{|c|}{ General information } & \multicolumn{8}{|c|}{ A horizon ${ }^{a}$} & \multirow{2}{*}{\multicolumn{2}{|c|}{$\frac{\text { C horizon }^{\mathrm{b}}}{\text { total Cd }}$}} \\
\hline \multirow[t]{2}{*}{ Origin } & \multirow[t]{2}{*}{$\begin{array}{c}\text { soil } \\
\text { type }^{9}\end{array}$} & \multirow[t]{2}{*}{ Land use } & \multirow[t]{2}{*}{ texture } & \multirow{2}{*}{$\begin{array}{l}\text { max. water holding } \\
\text { capacity } \\
\mathrm{g} \mathrm{H}_{2} \mathrm{O} / \mathrm{g} \text { soil }\end{array}$} & \multirow{2}{*}{$\begin{array}{c}\text { CEC } \\
\mathrm{mmol}_{\mathrm{c}} \mathrm{kg}^{-1} \\
\end{array}$} & \multirow{2}{*}{$\begin{array}{c}\text { pH } \\
\left(\mathrm{CaCl}_{2}\right) \\
\end{array}$} & \multirow{2}{*}{$\begin{array}{l}\text { C-content } \\
\mathrm{g} \mathrm{kg}^{-1} \\
\end{array}$} & \multicolumn{2}{|c|}{ total Cd } & \multicolumn{2}{|c|}{$\begin{array}{c}\mathrm{Ca}\left(\mathrm{NO}_{3}\right)_{2} \\
\text { extractable } \mathrm{Cd}\end{array}$} & & \\
\hline & & & & & & & & $\mathrm{ng} \mathrm{g}^{-1}$ & se $^{d}$ & $\mathrm{ng} \mathrm{g}^{-1}$ & $\mathrm{se}^{\mathrm{d}}$ & $\mathrm{ng} \mathrm{g}^{-1}$ & $\mathrm{se}^{\mathrm{d}}$ \\
\hline Oen & Cambisol & arable farming & silt loam & 0.51 & 164 & 5.6 & 24 & 508 & \pm 20 & 20.4 & \pm 9.8 & 152 & \pm 0.4 \\
\hline $\mathrm{LQ}$ & Fluvisol & arable farming & silt loam & 0.60 & 217 & 7.1 & 57 & 287 & \pm 3 & 2.75 & \pm 0.25 & 129 & \pm 4 \\
\hline
\end{tabular}

a The A horizons were sampled from 0-20 cm.

${ }^{b}$ The $\mathrm{C}$ horizons were provided by the Swiss National Soil Observation Program (NABO) from their archive.

${ }^{c}$ Plant-available $\mathrm{Cd}$ was extracted using $0.05 \mathrm{M} \mathrm{Ca}\left(\mathrm{NO}_{3}\right)_{2}$

${ }^{d}$ se denotes standard error of the mean $(n=2)$. 


\section{DM production, Cd concentration and Cd uptake of wheat}

A
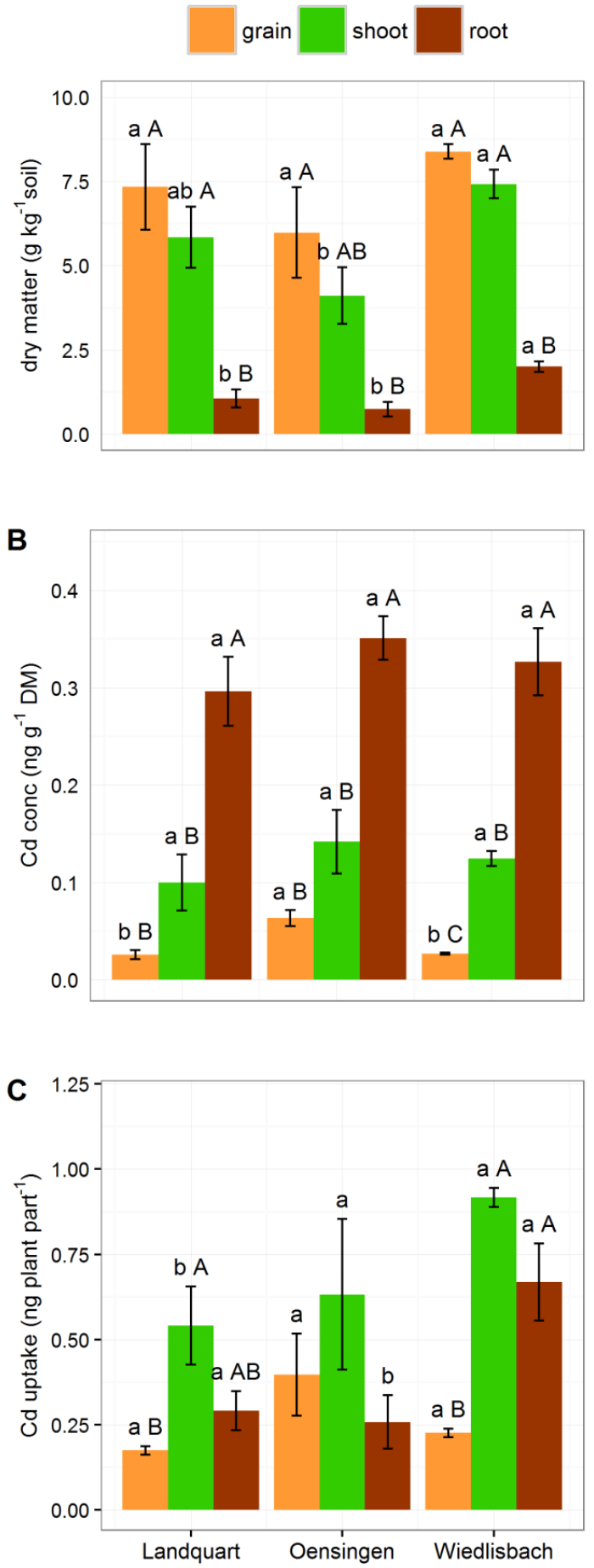

Figure S1 (A) Dry matter production, (B) Cd concentration and (C) Cd uptake of wheat grown on different soils under controlled conditions. Error bars indicate standard error $(n=4$ for LQ and Wied, $n=3$ for Oen). Upper case letters denote significant differences of the mean between different plant parts from wheat grown on the same soils. Lower case letters indicate significant differences between the same plant parts grown on different soils $(p<0.05)$. 


\section{Distribution of $\mathrm{Cd}$, macro and micronutrients in wheat}

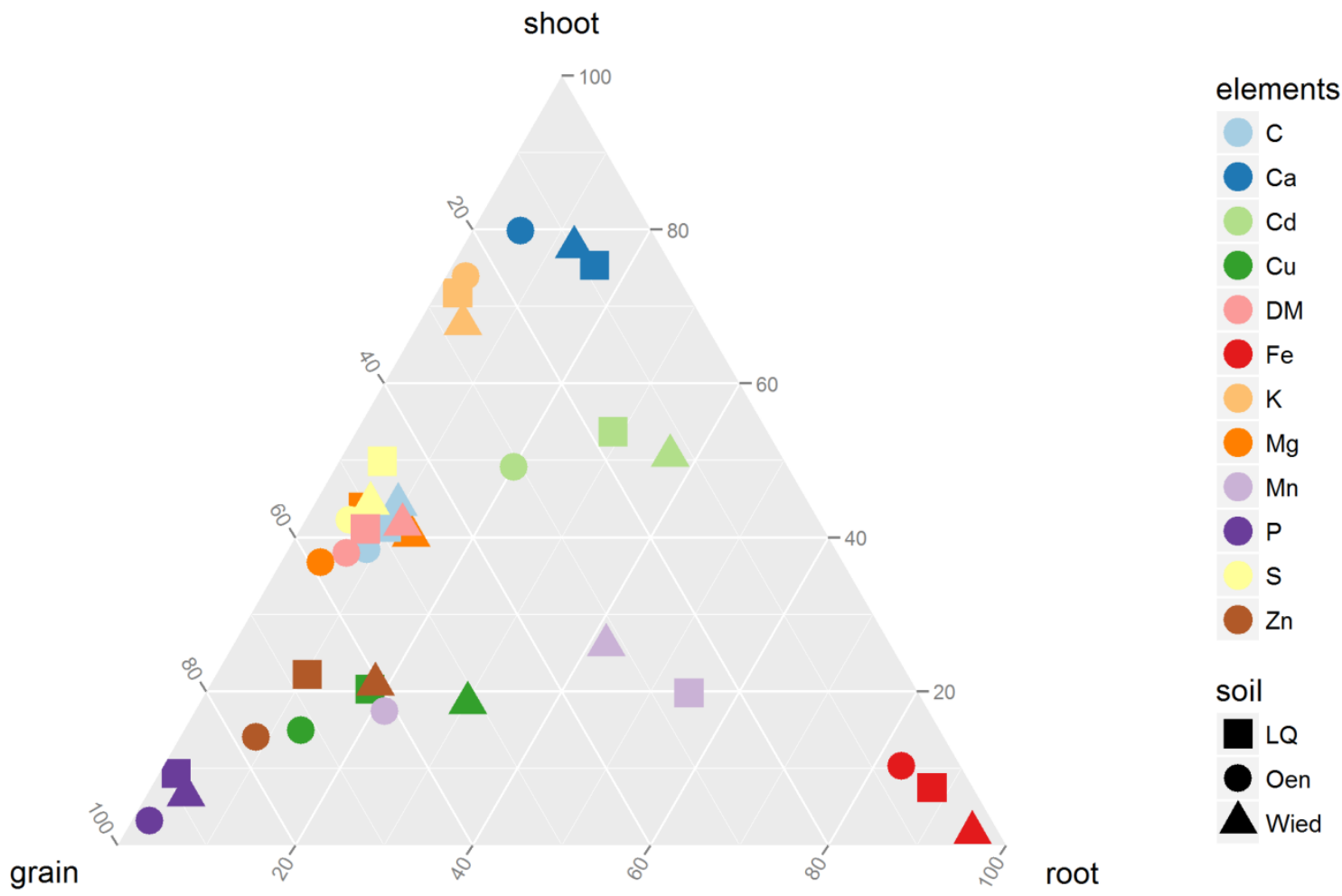

Figure S2: Relative distribution of $\mathrm{Cd}$, macro and micronutrients in the analyzed plant parts of wheat. Colors represent the elements measured and shapes represent the different soils. The values are given in percent, as calculated from the mean values (quantity of element as ng per plant part, $n=4$ ). $\mathrm{Cd}, \mathrm{Cu}$ and $\mathrm{Zn}$ were measured by ICP-MS; $\mathrm{Ca}, \mathrm{Fe}, \mathrm{K}, \mathrm{Mg}, \mathrm{Mn}$ and $\mathrm{P}$ were measured by ICP-OES; C and S by IRMS. 
Table S3: Element concentrations measured in the different wheat parts.

\begin{tabular}{|c|c|c|c|c|c|}
\hline element & unit & mean $^{b}$ & $\begin{array}{l}\text { standard } \\
\text { error }^{\mathrm{a}}\end{array}$ & soil & plant part \\
\hline \multirow{9}{*}{ C } & \multirow{9}{*}{$\mathrm{g} / \mathrm{kg} \mathrm{DM}$} & 416 & 1 & $\mathrm{LQ}$ & \multirow{3}{*}{ grain } \\
\hline & & 414 & 2 & Oen & \\
\hline & & 417 & 0 & Wied & \\
\hline & & 439 & 3 & $\mathrm{LQ}$ & \multirow{3}{*}{ straw } \\
\hline & & 441 & 1 & Oen & \\
\hline & & 451 & 1 & Wied & \\
\hline & & 415 & 1 & LQ & \multirow{3}{*}{ root } \\
\hline & & 435 & 3 & Oen & \\
\hline & & 360 & 19 & Wied & \\
\hline \multirow{9}{*}{$\mathrm{Ca}$} & \multirow{9}{*}{$\mathrm{g} / \mathrm{kg} \mathrm{DM}$} & 0.49 & 0.03 & $\mathrm{LQ}$ & \multirow{3}{*}{ grain } \\
\hline & & 0.56 & 0.03 & Oen & \\
\hline & & 0.41 & 0.04 & Wied & \\
\hline & & 5.40 & 0.40 & LQ & \multirow{3}{*}{ straw } \\
\hline & & 4.30 & 0.50 & Oen & \\
\hline & & 3.75 & 0.22 & Wied & \\
\hline & & 5.87 & 0.57 & $\mathrm{LQ}$ & \multirow{3}{*}{ root } \\
\hline & & 1.72 & 0.13 & Oen & \\
\hline & & 2.25 & 0.17 & Wied & \\
\hline \multirow{9}{*}{$\mathrm{Cd}$} & \multirow{9}{*}{$\mathrm{mg} / \mathrm{kg} \mathrm{DM}$} & 0.026 & 0.005 & LQ & \multirow{3}{*}{ grain } \\
\hline & & 0.063 & 0.008 & Oen & \\
\hline & & 0.027 & 0.001 & Wied & \\
\hline & & 0.100 & 0.029 & $\mathrm{LQ}$ & \multirow{3}{*}{ straw } \\
\hline & & 0.142 & 0.033 & Oen & \\
\hline & & 0.125 & 0.008 & Wied & \\
\hline & & 0.296 & 0.035 & LQ & \multirow{3}{*}{ root } \\
\hline & & 0.351 & 0.022 & Oen & \\
\hline & & 0.327 & 0.035 & Wied & \\
\hline \multirow{9}{*}{$\mathrm{Cu}$} & \multirow{9}{*}{$\mathrm{mg} / \mathrm{kg} \mathrm{DM}$} & 6.33 & 0.76 & $\mathrm{LQ}$ & \multirow{3}{*}{ grain } \\
\hline & & 5.11 & 0.93 & Oen & \\
\hline & & 4.28 & 0.05 & Wied & \\
\hline & & 2.58 & 0.23 & LQ & \multirow{3}{*}{ straw } \\
\hline & & 1.45 & 0.10 & Oen & \\
\hline & & 1.73 & 0.06 & Wied & \\
\hline & & 13.44 & 1.37 & LQ & \multirow{3}{*}{ root } \\
\hline & & 6.97 & 0.43 & Oen & \\
\hline & & 10.49 & 0.61 & Wied & \\
\hline \multirow{2}{*}{$\mathrm{Fe}$} & \multirow{2}{*}{$\mathrm{mg} / \mathrm{kg} \mathrm{DM}$} & 18 & 2 & LQ & \multirow{2}{*}{ grain } \\
\hline & & 26 & 2 & Oen & \\
\hline
\end{tabular}




\begin{tabular}{|c|c|c|c|c|c|}
\hline element & unit & mean & $\begin{array}{l}\text { standard } \\
\text { error }^{a}\end{array}$ & soil & plant part \\
\hline \multirow{7}{*}{$\mathrm{Fe}$} & \multirow{7}{*}{$\mathrm{mg} / \mathrm{kg} \mathrm{DM}$} & 35 & 1 & Wied & grain \\
\hline & & 42 & 16 & LQ & \multirow{3}{*}{ straw } \\
\hline & & 46 & 20 & Oen & \\
\hline & & 23 & 6 & Wied & \\
\hline & & 2280 & 254 & LQ & \multirow{3}{*}{ root } \\
\hline & & 2567 & 370 & Oen & \\
\hline & & 4708 & 392 & Wied & \\
\hline \multirow{9}{*}{ K } & \multirow{9}{*}{ g/kg DM } & 3.9 & 0.4 & LQ & \multirow{3}{*}{ grain } \\
\hline & & 4.8 & 0.4 & Oen & \\
\hline & & 4.0 & 0.2 & Wied & \\
\hline & & 13.9 & 1.3 & $\mathrm{LQ}$ & \multirow{3}{*}{ straw } \\
\hline & & 21.2 & 1.8 & Oen & \\
\hline & & 11.4 & 1.2 & Wied & \\
\hline & & 2.5 & 0.4 & LQ & \multirow{3}{*}{ root } \\
\hline & & 3.9 & 0.3 & Oen & \\
\hline & & 3.0 & 0.4 & Wied & \\
\hline \multirow{9}{*}{$\mathrm{Mg}$} & \multirow{9}{*}{$\mathrm{g} / \mathrm{kg} \mathrm{DM}$} & 1.2 & 0.1 & $\mathrm{LQ}$ & \multirow{3}{*}{ grain } \\
\hline & & 1.2 & 0.0 & Oen & \\
\hline & & 1.3 & 0.0 & Wied & \\
\hline & & 1.3 & 0.1 & LQ & \multirow{3}{*}{ straw } \\
\hline & & 1.0 & 0.2 & Oen & \\
\hline & & 1.3 & 0.1 & Wied & \\
\hline & & 0.9 & 0.1 & LQ & \multirow{3}{*}{ root } \\
\hline & & 0.8 & 0.1 & Oen & \\
\hline & & 1.5 & 0.1 & Wied & \\
\hline \multirow{9}{*}{$\mathrm{Mn}$} & \multirow{9}{*}{$\mathrm{mg} / \mathrm{kg} \mathrm{DM}$} & 2.6 & 0.4 & $\mathrm{LQ}$ & \multirow{3}{*}{ grain } \\
\hline & & 13 & 0.7 & Oen & \\
\hline & & 34 & 1.6 & Wied & \\
\hline & & 3.2 & 0.3 & LQ & \multirow{6}{*}{ straw } \\
\hline & & 5.0 & 0.8 & Oen & \\
\hline & & 31 & 6 & Wied & \\
\hline & & 39 & 5 & LQ & \\
\hline & & 40 & 7 & Oen & \\
\hline & & 185 & 10 & Wied & \\
\hline \multirow{6}{*}{$N$} & \multirow{6}{*}{$\mathrm{g} / \mathrm{kg} \mathrm{DM}$} & 20.2 & 1.5 & $\mathrm{LQ}$ & \multirow{3}{*}{ grain } \\
\hline & & 20.0 & 0.9 & Oen & \\
\hline & & 18.2 & 0.3 & Wied & \\
\hline & & 7.6 & 0.4 & $\mathrm{LQ}$ & \multirow{3}{*}{ straw } \\
\hline & & 6.3 & 1.0 & Oen & \\
\hline & & 6.9 & 0.0 & Wied & \\
\hline
\end{tabular}




\begin{tabular}{|c|c|c|c|c|c|}
\hline element & unit & mean & $\begin{array}{l}\text { standard } \\
\text { error }^{1}\end{array}$ & soil & plant part \\
\hline \multirow{9}{*}{$P$} & \multirow{9}{*}{ g/kg DM } & 3.53 & 0.52 & LQ & \multirow{3}{*}{ grain } \\
\hline & & 2.74 & 0.47 & Oen & \\
\hline & & 3.16 & 0.09 & Wied & \\
\hline & & 0.48 & 0.12 & LQ & \multirow{3}{*}{ straw } \\
\hline & & 0.12 & 0.01 & Oen & \\
\hline & & 0.26 & 0.02 & Wied & \\
\hline & & 0.55 & 0.07 & LQ & \multirow{3}{*}{ root } \\
\hline & & 0.41 & 0.06 & Oen & \\
\hline & & 0.65 & 0.06 & Wied & \\
\hline \multirow{9}{*}{$\mathrm{S}$} & \multirow{9}{*}{ g/kg DM } & 1.66 & 0.10 & LQ & \multirow{3}{*}{ grain } \\
\hline & & 1.52 & 0.07 & Oen & \\
\hline & & 1.55 & 0.02 & Wied & \\
\hline & & 2.45 & 0.56 & LQ & \multirow{3}{*}{ straw } \\
\hline & & 1.76 & 0.12 & Oen & \\
\hline & & 1.58 & 0.06 & Wied & \\
\hline & & 0.88 & 0.06 & LQ & \multirow{3}{*}{ root } \\
\hline & & 0.92 & 0.02 & Oen & \\
\hline & & 0.83 & 0.03 & Wied & \\
\hline \multirow{9}{*}{$\mathrm{Zn}$} & \multirow{9}{*}{$\mathrm{mg} / \mathrm{kg} \mathrm{DM}$} & 23.9 & 4.0 & LQ & \multirow{3}{*}{ grain } \\
\hline & & 18.9 & 0.8 & Oen & \\
\hline & & 25.3 & 0.9 & Wied & \\
\hline & & 9.9 & 1.5 & LQ & \multirow{3}{*}{ straw } \\
\hline & & 4.9 & 0.4 & Oen & \\
\hline & & 9.9 & 0.8 & Wied & \\
\hline & & 26.2 & 4.3 & LQ & \multirow{3}{*}{ root } \\
\hline & & 17.6 & 1.6 & Oen & \\
\hline & & 32.0 & 2.1 & Wied & \\
\hline \multirow{9}{*}{ DM } & \multirow{9}{*}{ g } & 7.3 & 1.3 & LQ & \multirow{3}{*}{ grain } \\
\hline & & 6.0 & 1.3 & Oen & \\
\hline & & 8.4 & 0.2 & Wied & \\
\hline & & 5.8 & 0.9 & LQ & stron \\
\hline & & 4.1 & 0.8 & Oen & Str dw \\
\hline & & 7.4 & 0.4 & Wied & \\
\hline & & 1.1 & 0.3 & LQ & root \\
\hline & & 0.7 & 0.2 & Oen & \\
\hline & & 2.0 & 0.2 & Wied & \\
\hline
\end{tabular}

${ }^{a}$ Standard error of the mean of $n=4$ samples

${ }^{b} \mathrm{Cd}$, Cu and $\mathrm{Zn}$ were determined by ICP-MS; Ca, Fe, K, Mg, Mn and P were determined by ICP-OES; C, N and S by IRMS. 
6. Apparent isotope fractionation between $\mathrm{A}$ horizon and $\mathrm{Ca}\left(\mathrm{NO}_{3}\right)_{2}$ extract

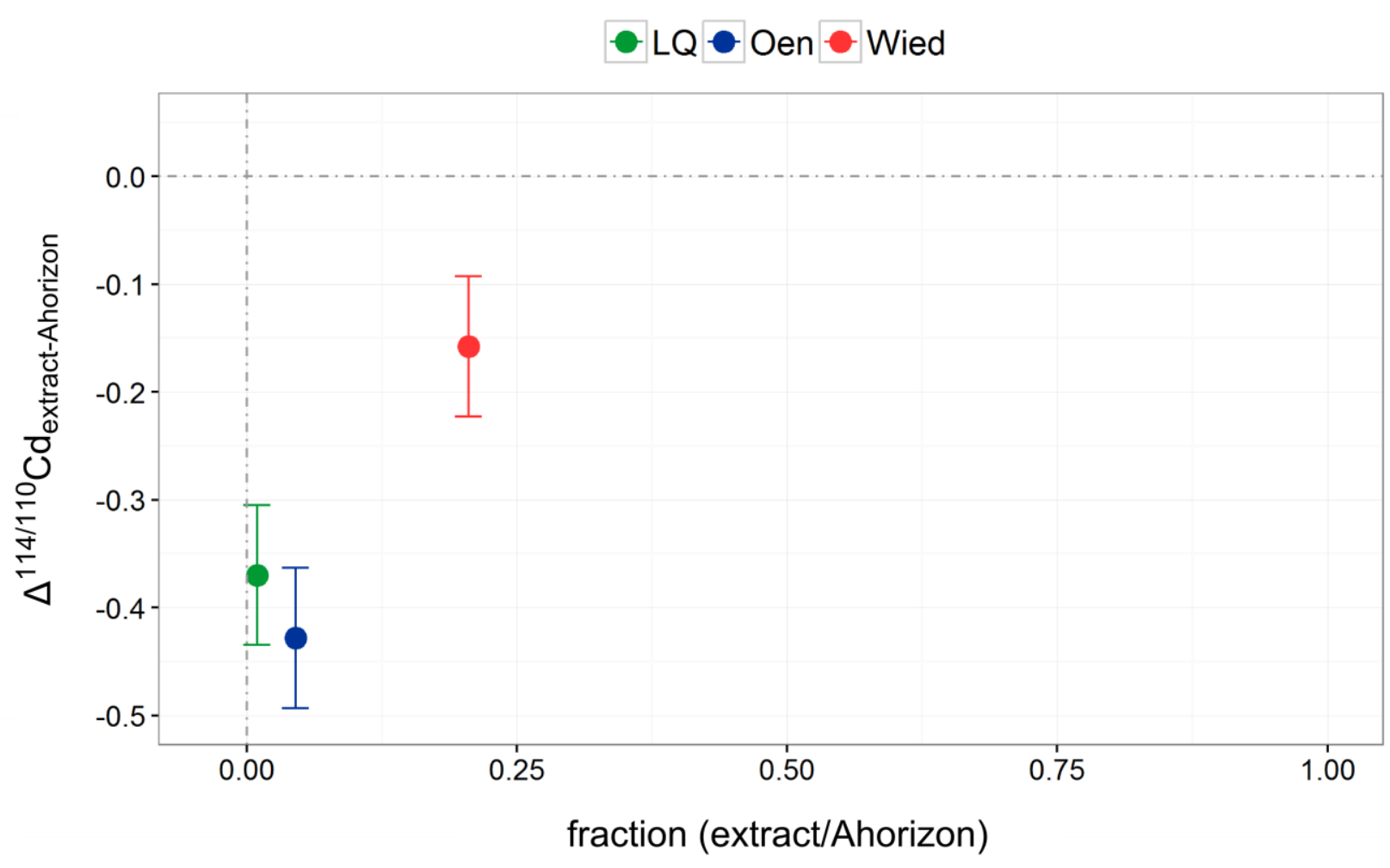

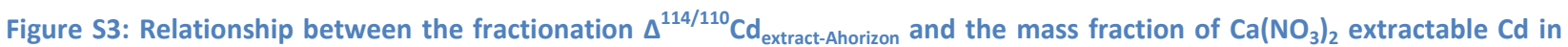
soil (relative to the total mass of $\mathrm{Cd}$ in the $\mathrm{A}$ horizon) 


\section{Cd isotope compositions (as $\delta^{114 / 110} \mathrm{Cd}$ values) of the soil-plant systems}

Table S4: Cadmium isotope compositions (as $\delta^{114 / 110} \mathrm{Cd}$ ) of the soil-wheat systems.

\begin{tabular}{ccccccc}
\hline & $\begin{array}{c}\text { Oen } \\
\delta^{114 / 110} \mathrm{Cd} \\
\% \text { Lo }\end{array}$ & SE & $\begin{array}{c}\delta^{114 / 110} \mathrm{Cd} \\
\%\end{array}$ & $\mathrm{SE}$ & $\begin{array}{c}\text { Wied } \\
\delta^{114 / 110} \mathrm{Cd} \\
\% \%\end{array}$ & $\mathrm{SE}$ \\
\hline grain & 0.62 & \pm 0.10 & 0.66 & \pm 0.04 & 0.59 & \pm 0.01 \\
straw & 0.52 & \pm 0.07 & 0.37 & \pm 0.04 & 0.09 & \pm 0.01 \\
root & 0.11 & \pm 0.05 & 0.13 & \pm 0.03 & -0.12 & \pm 0.02 \\
\hline $\begin{array}{c}\text { Ca(NO })_{2} \\
\text { extractable }\end{array}$ & 0.50 & \pm 0.05 & 0.54 & \pm 0.05 & 0.12 & \pm 0.05 \\
A horizon & 0.07 & \pm 0.01 & 0.09 & \pm 0.01 & -0.04 & \pm 0.01 \\
C horizon & 0.04 & \pm 0.02 & 0.00 & \pm 0.02 & -0.16 & \pm 0.02 \\
\hline
\end{tabular}

$S E=$ standard error of the mean, where $n=3$ for plant samples and $n=2$ for soil samples 


\section{Box model Oensingen}

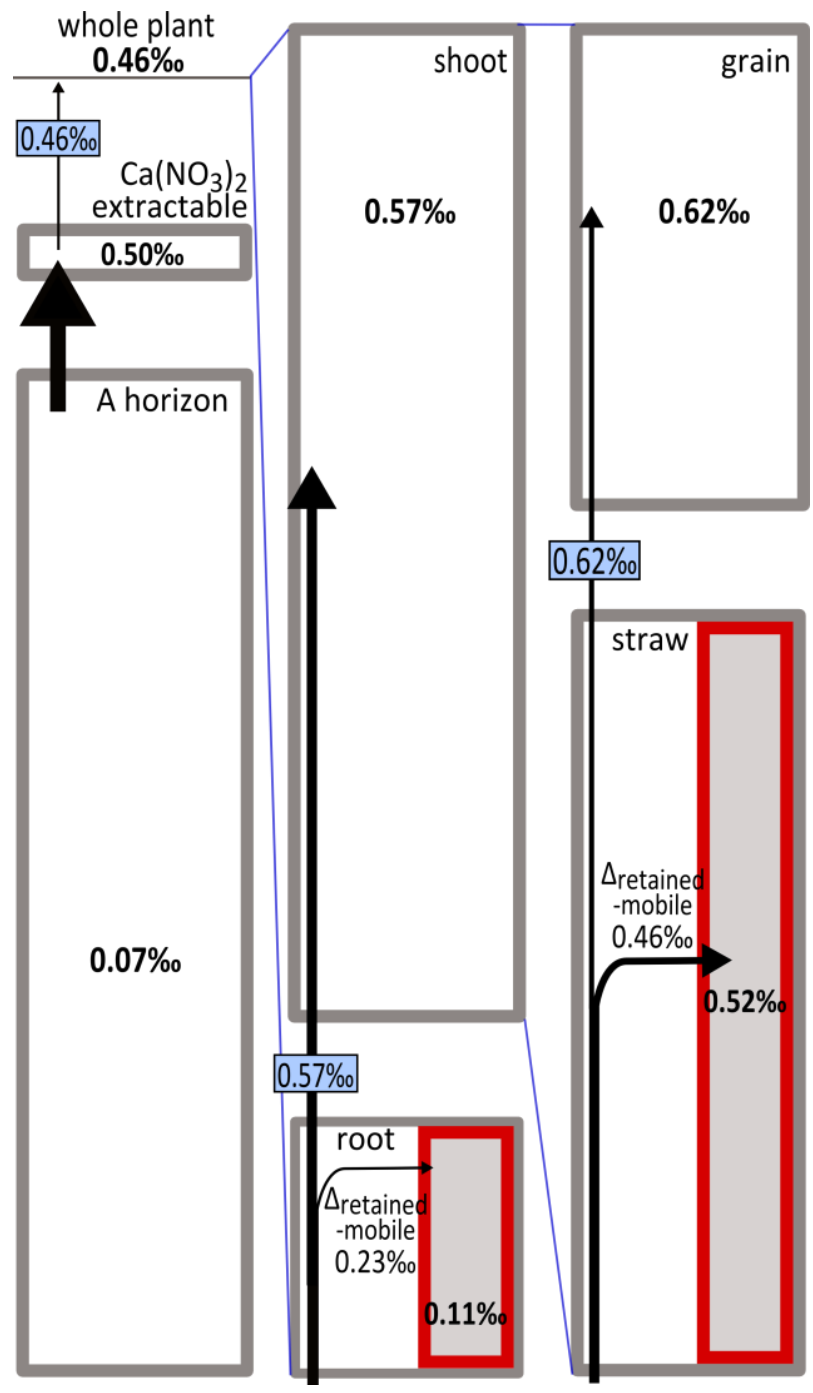

Figure S4: Box model that illustrates the $\mathrm{Cd}$ mass balance and isotope fractionation for the soil-wheat system at site Oensingen (Oen). Numbers in \%o represent average $\delta^{114 / 110} \mathrm{Cd}$ values. The $\delta$-values in the blue boxes represent the exported $\delta$-values from a soil pool or plant part (e.g., root) to the next soil pool or plant part (e.g., shoot). The exported $\delta$-values are identical to the $\delta$-value measured for the next soil pool or plant part (e.g., shoot). The $\Delta^{114 / 110} \mathrm{Cd}$ values were modeled with data from Oen, but also Wied and LQ as shown in Figure 3 and represent the apparent $\mathrm{Cd}$ isotope fractionation that results from retention of $\mathrm{Cd}$ in the respective plant part. The width of the arrows and size of the boxes are adapted to denote the relative sizes of the $\mathrm{Cd}$ fluxes and $\mathrm{Cd}$ pools, respectively. 


\section{Box model Landquart}

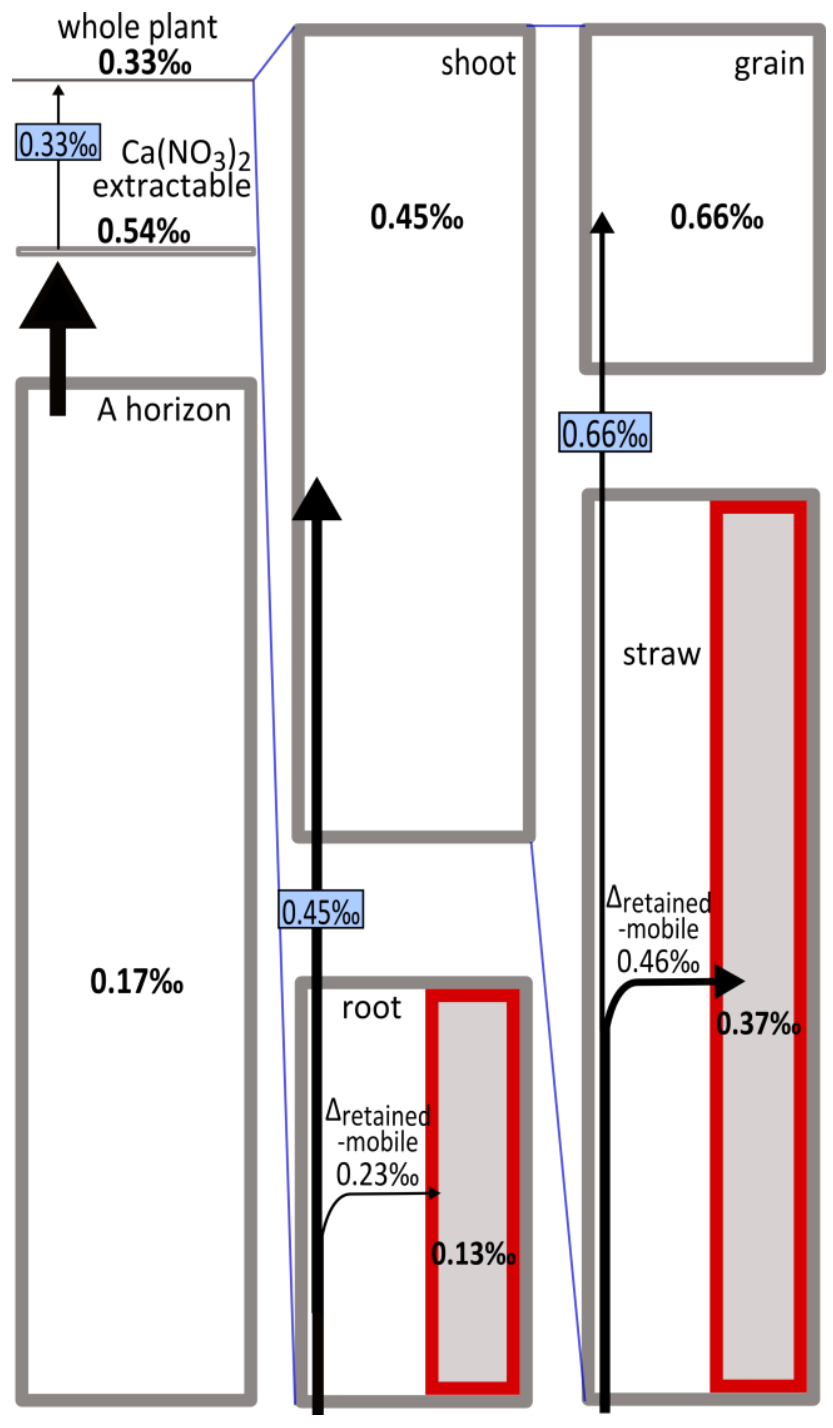

Figure S5: Box model that illustrates the Cd mass balance and isotope fractionation for the soil-wheat system at site Landquart (LQ). Numbers in \%o represent average $\delta^{114 / 110} \mathrm{Cd}$ values. The $\delta$-values in the blue boxes represent the exported $\delta$-values from a soil pool or plant part (e.g., root) to the next soil pool or plant part (e.g., shoot). The exported $\delta$-values are identical to the $\delta$-value measured for the next soil pool or plant part (e.g., shoot). The $\Delta^{114 / 110} \mathrm{Cd}$ values were modeled with data from LQ, but also Wied and Oen as shown in Figure 3 and represent the apparent $\mathrm{Cd}$ isotope fractionation that results from retention of $\mathrm{Cd}$ in the respective plant part. The width of the arrows and size of the boxes are adapted to denote the relative sizes of the $\mathrm{Cd}$ fluxes and $\mathrm{Cd}$ pools, respectively. 


\section{Comparison with published $\mathrm{Cd}$ isotope data for terrestrial and aquatic environments}

Figure $\mathrm{S} 6$ compares previously reported $\mathrm{Cd}$ isotope compositions for various terrestrial and aquatic environments with the plant data acquired in the present study. The comparison illustrates that rocks of the earth's mantle and crust, including fresh water sediments, show only limited isotopic variability with $\delta^{114 / 110} \mathrm{Cd}$ values of about $-0.4 \%$ and $0.4 \%$. In contrast, seawater and marine sediments and deposits show a much wider range in $\delta^{114 / 110} \mathrm{Cd}$, with values from $-0.45 \%$ to about $5 \%$. The most positive $\delta^{114 / 110} \mathrm{Cd}$ values are found in surface seawater, where dissolved $\mathrm{Cd}$ concentrations are extremely low, due to the uptake and storage of isotopically light Cd by phytoplankton., 10-12

In our study, samples in which $\mathrm{Cd}$ isotope fractionation was dominated by biological processes also showed a larger isotopic variation than samples in which $\mathrm{Cd}$ isotope fractionation was dominated by abiotic geological processes. The $\mathrm{A}$ and $\mathrm{C}$ soil horizons displayed a much smaller range of $\delta^{114 / 110} \mathrm{Cd}$ (from -0.09 to $-0.16 \%$ ) than the different wheat parts, which were characterized by $\delta^{114 / 110} \mathrm{Cd}=-0.12$ to $0.97 \%$. An important additional source of $\mathrm{Cd}$ isotope variation in the investigated soil-plant systems is the apparent fractionation between the A horizon and the $\mathrm{Ca}\left(\mathrm{NO}_{3}\right)_{2}$ extractable $\mathrm{Cd}$ of the soil (Figure 1). Notably, published $\mathrm{Cd}$ isotope data for birch leaves ${ }^{13}$ and $\mathrm{Cd}$-tolerant plants ${ }^{14}$ exhibit a similar range of $\delta^{114 / 110} \mathrm{Cd}$ values (from -0.39 to $1.3 \%$ ) as were measured here for the plant parts $(-0.12$ to $0.97 \%$ ) . 

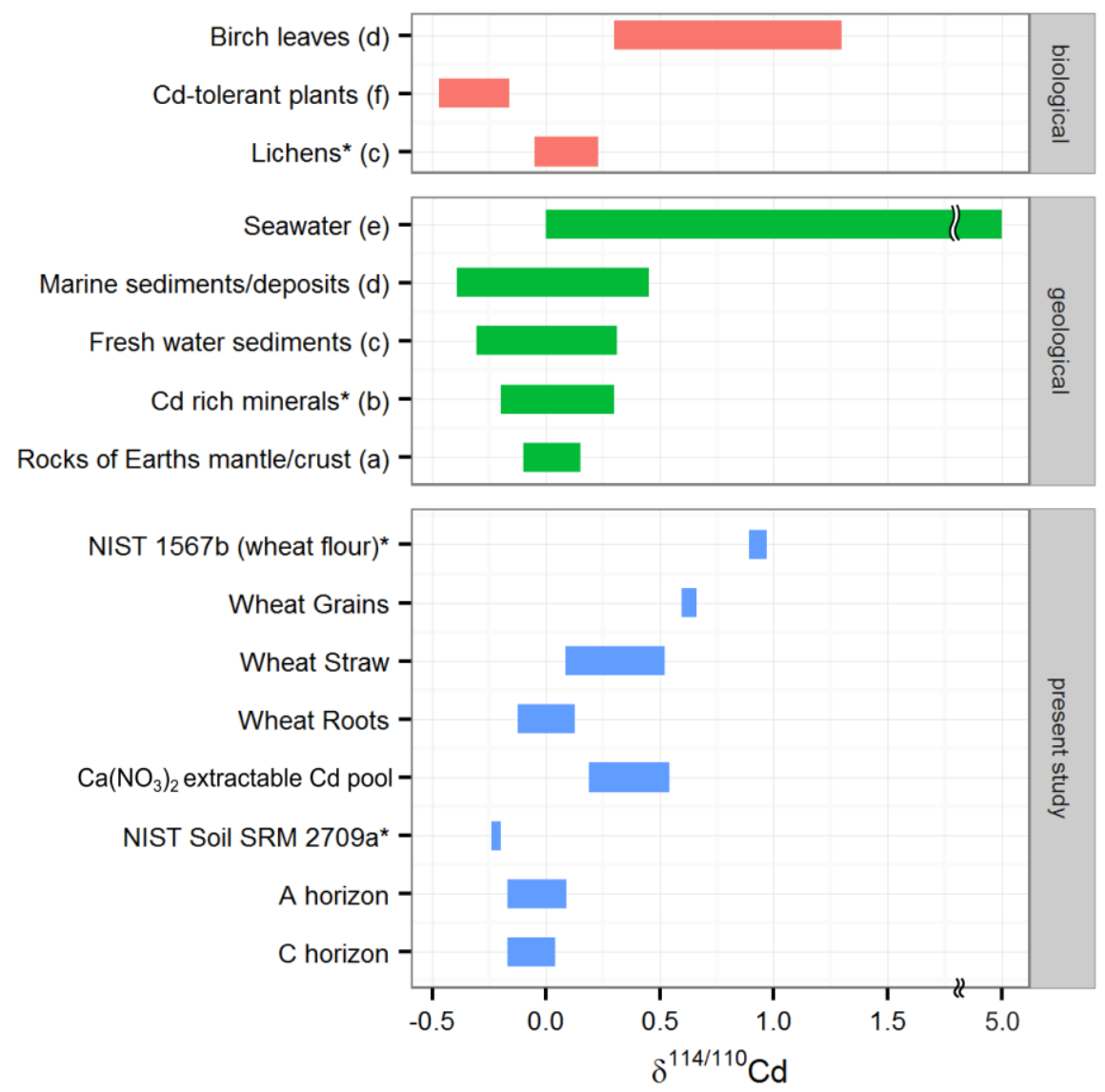

Figure S6: Summary of stable Cd isotope data $\left(\delta^{114 / 110} \mathrm{Cd}\right)$ for uncontaminated material in terrestrial and aquatic systems. Values are separated into biological and geological data and results obtained in the present study. Shown are the $\delta^{114 / 110} \mathrm{Cd}$ ranges of the samples unless the material ( $\mathrm{Y}$-axis) is marked with an asterisks, which indicates that the standard deviation of the dataset is plotted. All results are given relative to $\delta^{114 / 110} \mathrm{Cd}_{\text {NIST3108 }}=0$. Small letters refer to the data sources.

Sources: (a) Schmitt et al. ${ }^{15}$, Rehkämper et al. ${ }^{16}$, (b) Schmitt et al. ${ }^{15}$, Rehkämper et al. ${ }^{16}$, Wombacher et al. ${ }^{17}$, Shiel et al. ${ }^{18}$, (c) Pallavicini et al. ${ }^{13}$, (d) Schmitt et al. ${ }^{15}$, Horner et al. ${ }^{19}$, (e) Ripperger et al. ${ }^{3}$, Lacan et al. ${ }^{10}$, Conway \& John ${ }^{12}$, Abouchami et al. ${ }^{20}$, Xue et al. ${ }^{11}$, Rehkämper et al. ${ }^{16}$, (f) Wei et al. ${ }^{14}$, Wei et al. ${ }^{21}$ 


\section{Literature}

1. Böhm, W., Methods of studying root systems. Springer Verlag: Heidelberg, 1979.

2. Griffin, R. A.; Jurinak, J. J., Estimation of activity-coefficients from eectrical conductivity of natural aquatic sstems and soil extracts. Soil Sci 1973, 116, (1), 26-30.

3. Ripperger, S.; Rehkamper, M., Precise determination of cadmium isotope fractionation in seawater by double spike MC-ICPMS. Geochim Cosmochim Ac 2007, 71, (3), 631-642.

4. Xue, Z. C.; Rehkamper, M.; Schonbachler, M.; Statham, P. J.; Coles, B. J., A new methodology for precise cadmium isotope analyses of seawater. Anal Bioanal Chem 2012, 402, (2), 883-893.

5. Murphy, K.; Rehkamper, M.; Kreissig, K.; Coles, B.; Fliert, T. v. d., Improvements in Cd stable isotope analysis achieved through use of liquid-liquid extraction to remove organic residues from $\mathrm{Cd}$ separates obtained by extraction chromatography. $J$ Anal Atom Spectrom 2015.

6. Abouchami, W.; Galer, S. J. G.; Horner, T. J.; Rehkamper, M.; Wombacher, F.; Xue, Z. C.; Lambelet, M.; Gault-Ringold, M.; Stirling, C. H.; Schonbachler, M.; Shiel, A. E.; Weiss, D.; Holdship, P. F., A common reference material for Cadmium isotope studies - NIST SRM 3108. Geostand Geoanal Res 2013, 37, (1), 5-17.

7. Jochum, K. P.; Nohl, L.; Herwig, K.; Lammel, E.; Stoll, B.; Hofmann, A. W., GeoReM: A new geochemical database for reference materials and isotopic standards. Geostand Geoanal Res 2005, 29, (3), 333-338.

8. NIST Standard Reference Material 1567b, wheat flour; National Institute for Standards and Technology: https://wwws.nist.gov/srmors/view detail.cfm?srm=1567b, 2014.

9. WRB, F. W. G., World reference base for soil resources 2014, update 2015. International soil classification system for naming soils and creating legends for soil maps. In World Soil Resources Reports No. 106: Rome, 2015.

10. Lacan, F.; Francois, R.; Ji, Y. C.; Sherrell, R. M., Cadmium isotopic composition in the ocean. Geochim Cosmochim Ac 2006, 70, (20), 5104-5118.

11. Xue, Z. C.; Rehkamper, M.; Horner, T. J.; Abouchami, W.; Middag, R.; van de Flierdt, T.; de Baar, H. J. W., Cadmium isotope variations in the Southern Ocean. Earth Planet Sc Lett 2013, 382, 161-172.

12. Conway, T. M.; John, S. G., The cycling of iron, zinc and cadmium in the North East Pacific Ocean - Insights from stable isotopes. Geochim Cosmochim Ac 2015, 164, 262-283.

13. Pallavicini, N.; Engström, E.; Baxter, D. C.; Öhlander, B.; Ingri, J.; Rodushkin, I., Cadmium isotope ratio measurements in environmental matrices by MC-ICP-MS. J Anal Atom Spectrom 2014, 29, 1570-1584.

14. Wei, R.; Guo, Q.; Wen, H.; Yang, J.; Peters, M.; Zhu, C.; Ma, J.; Zhu, G.; Zhang, H.; Tian, L.; Wang, C.; Wan, Y., An analytical method for precise determination of the cadmium isotopic composition in plant samples using multiple collector inductively coupled plamsa mass spectrometry. Anlytical Methods 2015, 7, 2479-2487.

15. Schmitt, A. D.; Galer, S. J. G.; Abouchami, W., Mass-dependent cadmium isotopic variations in nature with emphasis on the marine environment. Earth Planet Sc Lett 2009, 277, (1-2), 262-272.

16. Rehkämper, M.; Horner, T. J.; Xue, Z.; Wombacher, F., Natural and anthropogenic Cd isotope variations. In Handbook of environmental isotope geochemistry, Baskaran, M., Ed. Springer: Heidelberg, 2011; Vol. 1, pp 125-154.

17. Wombacher, F.; Rehkamper, M., Investigation of the mass discrimination of multiple collector ICP-MS using neodymium isotopes and the generalised power law. J Anal Atom Spectrom 2003, 18, (11), 1371-1375.

18. Shiel, A. E.; Weis, D.; Orians, K. J., Evaluation of zinc, cadmium and lead isotope fractionation during smelting and refining. Science of the Total Environment 2010, 408, (11), 2357-2368.

19. Horner, T. J.; Schonbachler, M.; Rehkamper, M.; Nielsen, S. G.; Williams, H.; Halliday, A. N.; Xue, Z.; Hein, J. R., Ferromanganese crusts as archives of deep water Cd isotope compositions. Geochem Geophy Geosy 2010, 11, 1-10.

20. Abouchami, W.; Galer, S. J. G.; de Baar, H. J. W.; Alderkamp, A. C.; Middag, R.; Laan, P.; Feldmann, H.; Andreae, M. O., Modulation of the Southern Ocean cadmium isotope signature by ocean circulation and primary productivity. Earth Planet SC Lett 2011, 305, (1-2), 83-91.

21. Wei, R.; Guo, Q.; Wen, H.; Liu, C.; Yang, J.; Peters, M.; Hu, J.; Zhu, G.; Zhang, H.; Tian, L.; Han, X.; Ma, J.; Zhu, C.; Wan, Y., Fractionation of Stable Cadmium Isotopes in the Cadmium Tolerant Ricinus communis and Hyperaccumulator Solanum nigrum. Sci Rep 2016, 6, 1-9. 